COGNitive STUdies | ÉTUdES COGNITIVES, 10

JOANNA SATOŁA-STAŚKOWIAK

Institute of Slavic Studies, Polish Academy of Sciences, Poland

\title{
FROM MOMENTARITY TO PERFECTIVE MULTIPLICITY. DIFFERENT ASPECTS OF THE AORIST
}

\begin{abstract}
The aim of this work is a analysis of temporal meanings, and aspectual research. That problems raised in the article are analysed on concrete examples of past sentences translated from the Polish language into the Bulgarian language.

Keywords: momentarity, perfective multiplicity, aspectual forms, means of the aorist, translating.
\end{abstract}

\section{Introduction}

The works of V.Koseska, concerning the analysis of temporal meanings, and aspectual research by S. Karolak have become a starting point for this article. Being aware of the fact that the analysis of temporal meanings and aspectual analysis can be carried out separately, I have made an attempt to compare, for the purposes of the article, both topics in question.

It is worth emphasising that problems raised in the article are analysed on concrete examples of past sentences translated from the Polish language, which cannot be found in the works of the linguists mentioned above. There is a novelty value in an attempt to describe aspectual forms in a concrete type of the Polish past sentences translated by means of the aorist.

The Polish past sentences translated by the aorist form do not suggest the repetitiveness of events (although they can inform about the complexity of a presented event). They do not collocate with the expressions of the type: винаги (always), често (often), никога (never) || zawsze (always), często (often), nigdy (never) and the like. They are limited to the contexts where the operator of individuality occurs, cf. Koseska-Toszewa (2000).

Translation into the aorist is used in these Polish sentences whose most important purpose is to convey a concrete fact from the past, completed before the state of speech. I call them factive sentences (Koseska-Toszewa 2006).

Factive sentences locate an event, defining time thanks to temporal exponents placed within a sentence or other temporal exponents remaining outside a sentences in a surrounding context. This makes the meaning of the aorist fundamentally different from the meaning of imperfectum. E.g.: 


\section{I dated:}

pol. 5 II 1998 zakończyłem pisanie mojej książki. (JS) ${ }^{1}$

bułg. На 5 II 1998 завzрших писането на моята книга. (JS)

\section{II undated, contextually motivated:}

pol. Nieszczęsne zdarzenie wywróciło do góry nogami tok życia we wspólnocie. (Umberto Eco)

bułg. Нещастният случай обърка живота на братството. (Umberto Eco)

The analysis of temporal meanings of the aorist can be in principle carried out irrespective of the aspectual analysis. However, in this article two verb forms (more precisely- individual forms of the kinds of activities), out of six perfective aspectual forms occuring in the aorist sentences, are deliberately detailed in the light of temporal analysis.

The aspectual forms in the aorist sentences presented in this article-momentary and distributive- differ most, hence the need for looking at the sentences that contain them. The aorist momentary sentences describe an event by means of a simple, discontinuous aspectual form. A verb which is a constituent of such a sentence has a one-aspect character.

The other type of the analysed aorist sentences show an event which is prior to the state of speech by means of a three-aspect verb. Nonetheless, a discontinuous dominant predominates in the distributive aspect, therefore distributive sentences can present the temporal meaning of the aorist.

In this article, after Stanisław Karolak, three degrees of notional and morphological complexity of verbs are distinguised, thus distancing oneself from classical aspectology which did not accept such an approach "w każdym czasowniku kazała widzieć tylko jeden aspekt" (Karolak 2001a).

In the system of the Bulgarian language a particle of the aorist is a joint, amalgamatic exponent of a discontinuous aspect and the past tense. The aorist combined with the perfective theme reduplicates the discontinuity of the theme or its dominants, and as a result reduplication of aspect follows, cf. (Karolak 2001b). It means that a particle of the aorist does not expand aspectually the value of the theme so the forms of the aorist in this arrangement retain the aspect of the theme ${ }^{2}$. The aorist, however, remains an exponent of the past, i.e. it locates an event as simultaneous regarding another past state of affairs which is defined as a temporal point of reference. In case of complex themes, a temporal point of reference concerns only the dominant, whereas a subordinate continuous constituent (e.g. in the structure of distributives) is not located in time.

1 Translation by the author of the article (hereafter: JS).

2 Terms 'theme' and 'aspect of the theme' are understood as in the works of Karolak (2001a,b, 2008). 


\subsection{Momentary sentences are translated by means of the forms of the aorist - simple, discontinuous, momentary aspect (one-aspect verbs)}

This group is formed of sentences with verbs of momentary character: strzelit (fired), peckt (burst), spadt (fell down), błysnat (flashed) sometimes called 'time points'. Momentary sentences do not link in their structures a momentary verb and an adverbial showing a stretch in time, e.g. długo, w ciagu godziny (long, within an hour), as well as those which describe a slow course of action, e.g. dtugo błysnęło (it was flashing long).

Using momentary verbs, one can construct a sentence saying how many times a momentary event took place within a certain time, e.g.: W ciagu godziny kilkakrotnie błysnęło. Przez następnych kilka minut strzelił tylko raz, cf. (Śmiech 1971).

Momentary sentences link up with adverbials referring to 'time point'. An illustration of such adverbials are the following examples: nagle, niespodzianie, znienack $a$ and the like.

(1) pol. Samolot nagle wzbit się wysoko. (JS)

$\left(1^{\prime}\right)$ bułg. Изведнъж самолетьт литна високо. (JS)

(2) pol. Głos wzbit się niespodziewanie pod sklepienie kościoła niby korna prośba dziecięca. (Umberto Eco)

$\left(2^{\prime}\right)$ bułg. Тази призив литна неочаквано към сводовете на църквата като вопъл на дете. (Umberto Eco)

Whether a verb belongs to a group of momentary verbs is also determined by our knowledge of the world. We know from the observation of facts if the soaring of a plane lasts a moment. Similarly, we know how fast the voice of someone speaking will reach their listeners; cf. sentences (1) and (2).

(3) pol. Płamen roześmiał się. (JS)

$\left(3^{\prime}\right)$ bułg. Пламен се разсмя. (JS)

In order to classify a verb from sentence (3) to a group of momentary verbs, one has to recognise that a word roześmiat się (he burst out laughing) is close in its meaning to parsknat (he snorted with laughter). Then we understand that an event $<<$ bursting out $>>$ was sudden, spontaneous. Otherwise, a sentence Plamen burst out laughing can be included in a group of resultative sentences and then the result of such an utterance is, for example putting the participants of a conversation in a good mood.

(4) pol. Nagle jakaś wrzawa dobiegła naszych uszu od strony północnych drzwi. (JS)

$\left(4^{\prime}\right)$ bułg. Изведнъж откъм северната врата долетя глъчка. (JS)

An adverbial suddenly refers to 'time point' and suggests momentarity of an event "reaching" indicated by the sentence: 
(5) pol. Tęcza rozświetliła rozmaitymi kolorami witraże. (Umberto Eco)

$\left(5^{\prime}\right)$ bułg. Дъгата разясни разноцветните стъкла. (Umberto Eco)

(6) pol. Skąd ci przyszedt na myśl Aulus Plaucjusz? (Henryk Sienkiewicz)

$\left(6^{\prime}\right)$ bułg. Откъде ти дойде наум за Авъл Плавций? (Henryk Sienkiewicz)

Sentence (6) refers to a sudden event, the knowledge of a human being tells us that he or she has no influence on the workings of their mind and human thoughts / associations appear suddenly, without previous plan. What also shows this sudden change in the way of thinking is the fact that a person asking a question is genuinely surprised by the interlocutor's line of thought.

\subsection{Distributive sentences translated by means of the form of the aorist - distributive aspect with discontinuous dominant (three-aspect verbs)}

A condition for being assigned to a group of distributive sentences is the multiplicity of events. In distributive sentences there are perfective and at the same time multiple verbs such as powypisywać, powykreślać, powyjeżdżá, powymazywać (write sth, draw sth, go away, to rub sth out over and over again) and the like. Distributive sentences describe many completed events which follow each other one by one. However, they are not unambiguous and it is often impossible to replace the verb forms occuring in distributive sentences with other perfective verbs.

Popalit wszystkie notatki. $=$ Spalit wszystkie notatki. (He set fire to all the notes. $=$ He burnt all the notes.)

(1) pol. Gruszki pospadały z drzewa. (JS)

(1') bułg. Крушите изпопадаха от дърветата. (JS)

Sentence (1) describes the falling of apples from a tree (multiplication). These events, however, have a strongly marked limit (prefix po) - hence the certainty that they took place before the state of speech. A verb pospadaty ((apples) fell) is a three-aspect one. In order to form a sentence of this type, the multiplicity of events has to occur.

(2) pol. Wszystkie dziewczyny powychodzity już za maż. (JS)

$\left(2^{\prime}\right)$ bułg. Всичките момичета вече се изпомбжиха. (JS)

In sentence (2) the girls were getting married until each of them became married. However, it did not take place for all the women at the same time.

(3) pol. Posprzedawała te książki. (JS)

$\left(3^{\prime}\right)$ bułg. Тя изпродаде тези книги. (JS)

The books from sentence (3) were being sold by their owner and finally the woman sold them all.

(4) pol. Sprzedawca powywieszat tu sukienki. (JS)

$\left(4^{\prime}\right)$ bułg. Продавач понакачи тука и там рокличките. (JS)

The task of a shop assistant from sentence (4) was displaying dresses in a shop window. The man completed his task, he was displaying the merchandise until he finally displayed it. 


\section{Summary}

It is known that a semantic category of time locates a given temporal situation (it can be a state, an event or randomly complex combination of states and events, also called a process) by means of a previousness-sequentiality relation with reference to the state of speech. However, a semantic category of aspect (which includes the kinds of activities) examines the previousness-sequentiality relation in isolation from the state of speech. In case of a semantic category of aspect a relation of the situation described (it can be a state, an event or a process) to the state of speech is not a fundamental, important one. However, it is, as the presented material shows, extremely interesting.

The kind of activity of a verb can have an influence on the choice of a specific verbal form. Thus, the distribution of typical verbal (as possible exponents of temporality) and aspectual forms can mesh, as well as condition each other.

The Polish past momentary and distributive sentences translated into the form of the aorist include aspectual perfective verbs which differ significantly in a detailed morfological and semantic analysis. As the presented material shows, the Polish past sentences translated into the form of the Bulgarian aorist are not homogenous. However, the factive sentences are a denominator that combines them. The way the Polish past sentences compared in this article are translated into the forms of the Bulgarian aorist is closely connected with the need for pointing out a concrete fact which arose in the past before the state of speech by means of temporal exponents located explicite or implicite. Irrespective of the fact how aspectually complex a perfective verb within a past sentence is, it does not combine with expressions of the type : zawsze (always), często (often), nigdy (never) \| винаги (always), често (often), никога (never) and the like. Polish and Bulgarian sentences are restricted to the contexts where the operator of individuality occurs.

It is worth emphasising that the kind of sentences affects the occurrance of the discussed verbal forms.

\section{References}

Koseska-Toszewa, V. (2000). Aoryst i perfekt bułgarski (na marginesie Gramatyki konfrontatywnej bułgarsko-polskiej, vol.7, part 2 Temporalność), Studia z Filologii Polskiej i Słowiańskiej, 36, Slawistyczny Ośrodek Wydawniczy, Warszawa, pages 193-212.

Koseska-Toszewa, V. (2000). O związkach aspektu i czasu (na przykładzie gwar bułgarskich i języka literackiego), Studia z Filologii Polskiej i Słowiańskiej, 37, Slawistyczny Ośrodek Wydawniczy, Warszawa, pages 189-201.

Satoła-Staśkowiak, J. (2006). Ekwiwalencje przekładowe polskich zdań praeterytalnych na bułgarski aoryst i imperfectum, In Koseska-Toszewa, V., Roszko, R. (Eds.) Semantyka a konfrontacja językowa 3, Slawistyczny Ośrodek Wydawniczy, Warszawa, pages 231-249.

Karolak, S. (2001). Inchoatywność i rezultatywność w języku bułgarskim, In Karolak, S. (2001) Od semantyki do gramatyki, Slawistyczny Ośrodek Wydawniczy, Warszawa, pages 637-652. 
Karolak, S. (2001). Metodologia analizy aspektualnej a aspekt w języku bułgarskim, In Karolak, S. (2001) Od semantyki do gramatyki, Slawistyczny Ośrodek Wydawniczy, Warszawa, pages 615-635.

Karolak, S. (2008). Karolak, S. (2008). Gramatyka konfrontatywna butgarsko-polska. vol. 8. Semantyczna kategoria aspektu, Slawistyczny Ośrodek Wydawniczy, Warszawa.

Śmiech, W. (1971). Funkcje aspektów czasownikowych we wspótczesnym języku ogólnopolskim, Łódzkie Towarzystwo Naukowe, Łódź. 